\title{
Analisis Keputusan Auditor Switching Voluntary Perusahaan Manufaktur Yang Terdaftar Di BEI Tahun 2015-2017
}

\author{
Fitria Magdalena Suprapto \\ Universitas Islam Kadiri \\ fitria_magdalenaa@yahoo.com
}

\section{Wawan Cahyo Nugroho}

Sekolah Tinggi Ilmu Ekonomi Indonesia Surabaya

wawancahyonugroho@stiesia.ac.id

\begin{abstract}
Abstrak Tujuan dari penelitian ini adalah untuk mendeskripsikan pengaruh Pergantian Manajemen, Audit Fee, dan Audit Delay terhadap keputusan Auditor Switching Voluntary pada perusahaan Manufaktur yang terdaftar di BEI tahun 2015-2017. Adapun manfaat hasil penelitian ini diharapkan dapat sebagai penambah wawasan dan masukan yang positif bagi perusahaan, investor, dan literatur atas Auditor Switching Voluntary. Pendekatan penelitian ini adalah kuantitatif dengan menggunakan alat analisis data regresi logistik. Dengan menggunakan metode purposive sampling didapatkan sampel yang dapat diteliti sejumlah 111 perusahaan manufaktur dengan 333 laporan keungan tahunan. Hasil penelitian menunjukkan nilai signifikansi Pergantian Manajemen dan Audit Fee lebih besar dari 0,05 yang berarti tidak berpengaruh dan tidak signifikan terhadap Auditor switching Voluntary. Audit Delay memiliki nilai signifikansi 0,006 lbih kecil dari 0,05 yang berarti memiliki pengaruh dan signifikan terhadap Auditor Switching Voluntary.

Kata Kunci Auditor Switching Voluntary, Pergantian Manajemen, Audit Fee, Audit Delay
\end{abstract}

\section{PENDAHULUAN}

Laporan keuangan merupakan suatu produk akhir pihak manajemen yang berisi sekumpulan informasi yang digunakan sebagai alat pengambil keputusan oleh pihak yang berkepentingan. Informasi yang disajikan berupa posisi keuangan, kinerja, dan perubahan posisi keuangan yang berguna bagi pihak eksternal (prinsipal) maupun internal (agen). Pihak eksternal mengharapkan suatu laporan keuangan yang tidak bias dan mencerminkan keadaan perusahaan yang sebenarnya atau bebas dari salah saji sehingga tidak diragukan kewajarannya. Sementara pihak manajemen (agen) selaku penyaji informasi cenderung untuk menginginkan informasi yang dapat menguntungkan pribadinya. Perbedaan kepentingan ini diyakini dapat diatasi dengan kehadiran auditor yang independen sebagai penengah untuk memberikan keyakinan yang memadai atas laporan keuangan yang bebas salah saji (Robbitasari \& Wiratmaja, 2013)

Berdasarkan data dari (http://www.ojk.go.id) per bulan Juli tahun 2019 terdapat $649 \mathrm{KAP} / \mathrm{AP}$ yang telah terdaftar dan berstatus aktif. Banyaknya jumah KAP yang beroperasi saat ini, memungkinkan perusahaan untuk melakukan pergantian KAP yang dikenal dengan istilah auditor switching. Pemerintah telah mengatur melalui Peraturan 
Pemerintah (PP) Republik Indonesia No. 20 Tahun 2015 tentang Praktik Akuntan Publik (PP/20/2015) tentang Akuntan Publik, juga mengatur tentang pergantian jasa auditor menyebutkan pada ayat (1) pemberian jasa audit atas informasi keuangan historis sebagaimana dimaksud dalam pasal 10 ayat (1) huruf a terhadap suatu entitas oleh seorang Akuntan Publik dibatasi paling lama untuk 5 (lima) tahun buku berturut-turut. Namun hingga saat ini, masih terdapat perusahaan yang melakukan pergantian auditor secara sukarela. Akhirnya muncul berbagai pertanyaan ketika perusahaan melakukan auditor switching secara sukarela.

Perusahaan pastinya menginginkan laporan keuangannya mendapat opini wajar tanpa pengecualian (WTP) dari KAP, karena opini ini akan berpengaruh terhadap keputusan investasi pihak eksternal. Saat auditor tidak dapat memberikan opini WTP, perusahaan kemungkinan akan berpindah ke KAP yang dapat memberikan opini sesuai dengan yang diharapkan perusahaan. Adanya pergantian manajemen dalam perusahaan cenderung memiliki pengaruh terhadap pergantian auditor karena seorang manajer tentu memiliki gaya kepemimpinan yang berbeda-beda sehingga memungkinkan terjadinya perubahan kebijakan dari kepemimpinan yang sebelumnya (Sinarwati, 2010). Mereka berharap bahwa KAP yang baru akan lebih bisa luwes diajak bekerja sama dan bisa memberikan opini seperti yang diharapkan.

Faktor lain yang menjadi pertimbangan perusahaan sebelum memulai perikatan dengan KAP adalah biaya yang harus dikeluarkan selama proses audit. Biaya audit ini bervariasi tergantung pada tingkat risiko dan kompleksitas jasa yang diberikan. Perusahaan dengan kondisi kesulitan keuangan berpotensi menutup usahanya dan cenderung melakukan pergantian auditor dikarenakan kesulitan dalam membayar audit fee (Astuti \& Ramantha, 2014).

Rentang waktu dalam menyelesaikan pekerjaan audit sampai tanggal diterbitkannya laporan disebut audit delay. Batas waktu pengerjaan audit ini telah diatur dalam peraturan BAPEPAM No. KEP-346/BL/2011 tentang penyampaian laporan keuangan berkala emiten atau perusahaan publik, yang menyatakan bahwa laporan keuangan tahunan perusahaan wajib disampaikan kepada BAPEPAM dan LK dan diumumkan kepada masyarakat paling lambat pada akhir bulan ketiga setelah tanggal laporan keuangan tahunan. Bagi perusahaan, dengan adanya peraturan ini tidak menutup kemungkinan baginya untuk menjadi alasan dalam mengganti auditor yang lalai atas batas waktu yang telah ditetapkan. Berdasarkan hasil penelitian yang dilakukan oleh (Arisudhana, 2017) menunjukkan bahwa audit delay pada perusahaan sub sektor property dan real etate yang terdaftar pada Bursa Efek Indonesia Periode 2011-2015 memiliki pengaruh secara signifikan terhadap auditor switching.

Fenomena mengenai auditor switching memang sangat menarik untuk diteliti, mengingat terdapat pihak yang mendukung dan bahkan menentangnya. PT Inovisi Infracom Tbk merupakan contoh perusahaan yang melakukan auditor switching secara sukarela terhadap laporan keuangan perusahaan untuk tahun buku 2014. Setelah otoritas BEI melakukan penelaahan terhadap laporan keuangan perusahaan kuartal III-2014, diketahui terdapat delapan poin dalam laporan keuangan perusahaan yang mencurigakan, yakni tidak sinkron dan banyak ditemukan kesalahan. Manajemen PT Inovisi Infracom Tbk menyanggupi untuk memperbaiki laporan keuangannya sehingga menunjuk KAP yang baru untuk melakukan pengauditan. Perusahaan tersebut menunjuk Kreston International (Hendrawinata, Eddy Siddharta, Tanzil, dan rekan) untuk mengaudit laporan kinerja keuangannya yang sebelumnya dilakukan oleh KAP Jamaludin, Ardi, 
Sukimto, dan rekan pada audit laporan keuangan 2013. Sanksi yang diberikan oleh PT Bursa Efek Indonesia (BEI) ialah berupa penghentian sementara (suspensi) perdagangan saham (http://detikfinance.com). Hal inilah yang memotivasi peneliti melakukan penelitian dalam bidang voluntary auditor switching untuk mengetahui motivasi perusahaan. Penelitian ini menganalisis keputusan Auditor Switching Voluntary pada Perusahaan Manufaktur yang terdaftar di BEI tahun 2015-2017.

\section{LANDASAN TEORI}

\section{Teori Agensi}

Teori ini melandasi sebuah agency problem atau teori yang menjelaskan tentang permasalahan hubungan kontrak antara agen dan prinsipal. Agency problem muncul karena setiap manusia memiliki kecenderungan untuk mementingkan diri sendiri dan dapat menimbulkan konflik disaat beberapa kepentingan bertemu secara bersamaan. Kondisi konflik ini diperparah apabila masing-masing pihak yang berkonflik memiliki ketidaklengkapan informasi (asimetri informasi) terhadap individu yang lain. Salah satu upaya yang dapat dilakukan untuk mengurangi dampak negatif karena adanya asimetri informasi tersebut adalah dengan menunjuk Kantor Akuntan Publik yang independen. Perikatan ini bertujuan untuk mendapatkan informasi yang lebih independen tentang prestasi kerja dan kualitas kerja laporan keuangan.

\section{Auditor Switching}

Auditor switching merupakan perilaku yang dilakukan oleh perusahaan atau klien dalam melakukan pergantian kantor akuntan publik disebabkan karena adanya kewajiban rotasi audit. Auditor switching dapat bersifat sukarela (voluntary) dan wajib (mandatory). Perusahaan yang mengganti KAP-nya secara wajib (mandatory) merupakan tindakan perusahaan berdasarkan dengan peraturan yang telah ditetapkan, sedangkan pergantian auditor yang dilakukan secara sukarela (voluntary) merupakan tindakan perusahaan dalam melakukan pergantian auditor atau KAP tanpa adanya peraturan yang mewajibkan melakukan auditor switching atau terjadi karena suatu alasan dari pihak klien maupun dari KAP.

\section{Pergantian Manajemen terhadap Auditor Switching}

Pergantian manajemen bisa disebabkan oleh keputusan rapat umum pemegang saham (RUPS) atau adanya pengunduran diri dari pihak manajemen sehingga pemegang saham harus mengganti dengan manajemen yang baru. Setiap manajer memiliki gaya kepemimpinan yang berbeda-beda, dengan pergantian manajemen yang baru, tidak menutup kemungkinan akan adanya perubahan kebijakan dalam bidang akuntansi, keuangan, dan pemilihan KAP. (Wijayani, 2011) melakukan penelitian tentang pengaruh pergantian manajemen terhadap pergantian auditor. Hasil penelitian tersebut menyebutkan bahwa terdapat hubungan antara pergantian manajemen dengan pergantian auditor. Hasil yang berbeda ditunjukkan oleh (Damayanti \& Sudarma, 2008) yang menunjukkan bukti bahwa pergantian manajemen tidak berhubungan positif dengan auditor switching.

$\mathrm{H}_{1}$ : Pergantian manajemen berpengaruh terhadap auditor switching

\section{Audit Fee terhadap Auditor Switching}


Auditfee adalah imbalan berupa sejumlah uang yang ditawarkan oleh KAP kepada perusahaan berkaitan dengan pekerjaan audit dengan dasar pembebanan waktu dan biaya yang digunakan auditor dalam menjalakan keahliannya. Besaran audit fee menggambarkan reputasi KAP di mata masyarakat, yakni keahlian auditor professional dalam menjalankan profesinya. Penawaran audit fee yang terlalu mahal atau melampaui batas toleransi yang ditetapkan perusahaan akan semakin membebani perusahaan dan mendorong untuk melakukan pergantian KAP meskipun mereka harus melepas KAP yang biasa mereka gunakan untuk mengaudit laporan keuangan perusahaan (Damayanti \& Sudarma, 2008). (Nasir, 2018) melakukan penelitian yang menunjukkan bahwa audit fee memengaruhi auditor switching dengan financial distress sebagai variabel moderasi. Namun hasil penelitian yang dilakukan oleh (Chadegani, Mohamed, \& Jari, 2011) menunjukkan hasil yang berbeda yang menemukan bahwa audit fee tidak berpengaruh signifikan terhadap pergantian KAP di Malaysia.

$\mathrm{H}_{2}$ : Audit fee berpengaruh terhadap auditor switching

\section{Audit Delay terhadap Auditor Switching}

Audit delay merupakan rentang waktu bagi auditor dalam menyelesaikan pekerjaan audit hingga tanggal diterbitkannya laporan. Pengukuran waktu audit delay berdasarkan lamanya hari yang dibutuhkan bagi perusahaan untuk memperoleh laporan auditor independen atas laporan keuangan tahunan perusahaan, yakni sejak tanggal tutup buku laporan keuangan perusahaan sampai dengan tanggal yang tertera pada laporan auditor independen (Praptika \& Rasmini, 2016). Rentang waktu audit delay ini dipengaruhi oleh kerumitan selama proses audit. Berdasarkan peraturan BAPEPAM No. KEP-346/BL/2011 tentang penyampaian laporan tahunan wajib disampaikan kepada BAPEPAM dan LK dan diumumkan kepada masyarakat paling lambat pada akhir bulan ketiga setelah tanggal laporan keuangan tahunan. Hasil penelitian (Soraya \& Haridhi, 2017) menyatakan bahwa terdapat pengaruh audit delay terhadap auditor switching. Namun hasil yang berbeda ditunjukkan oleh (Sari, Deviyanti, \& Kusumawardani, 2018) yang menyatakan bahwa variabel audit delay tidak berpengaruh secara signifikan terhadap voluntary auditor switching.

$\mathrm{H}_{3}$ : Audit delay berpengaruh terhadap auditor switching

\section{METODOLOGI PENELITIAN}

Penelitian ini menggunakan pendekatan kuantitatif dengan sumber data sekunder yang berasal dari laporan keuangan tahunan auditan. Populasi yang digunakan dalam penelitian ini adalah perusahaan manufaktur yang terdaftar di Bursa Efek Indonesia dari periode tahun 2015-2017 yang berjumlah 138 perusahaan. Teknik pengambilan sampel dalam penelitian ini menggunakan metode purposive sampling, yaitu perusahaan manufaktur yang menerbitkan laporan keuangan tahunan disertai surat penyataan direksi dan laporan auditor independen secara konsisten di BEI selama periode 2015-2017. Dari ketentuan tersebut, jumlah sampel perusahaan yang dapat diteliti adalah 111 perusahaan sehingga terdapat 333 laporan keungan tahunan. Penelitian ini menggunakan alat analisis data regresi logistik (logistic regression).

\section{HASIL PENELITIAN \\ 4.1. Statistik Deskriptif}


Hasil analisis distribusi frekuensi terhadap perusahaan yang melakukan auditor switching sebanyak 15,9\% atau sebanyak 53 sampel, sedangkan sampel yang tidak melakukan auditor switching sebanyak 84,1\% atau sebesar 280 sampel. Berdasarkan hasil distribusi frekuensi tersebut dapat disimpulkan bahwa perusahaan manufaktur yang melakukan auditor switching lebih kecil dibandingkan perusahaan yang tidak melakukan auditor switching. Hasil analisis distribusi frekuensi terhadap perusahaan yang melakukan pergantian manajemen sebanyak 79 sampel perusahaan atau sebesar $23,7 \%$ sedangkan sampel perusahaan yang tidak melakukan pergantian manajemen sebanyak 254 atau sebesar 76,3\%. Hal ini menunjukkan bahwa hanya sedikit perusahaan yang melakukan pergantian manajemen selama periode penelitian.

Hasil analisis distribusi frekuensi terhadap audit fee menunjukkan bahwa terdapat 5 sampel perusahaan atau sebesar 1,5\% sampel perusahaan yang beralih dari menggunakan KAP non Big-four ke KAP Big-four, sedangkan sisanya sebesar 328 sampel perusahaan atau 98,5\% yang tidak terjadi perpindahan kelas dari KAP non Bigfour ke KAP Big-four. Hasil analisis distribusi frekuensi terhadap auditdelay menunjukkan bahwa terdapat 24 sampel perusahaan atau sebesar 7,2\% sampel perusahaan yang mengalami audit delay, sementara sampel perusahaan yang tidak mengalami audit delay sebesar 309 atau 92,8\%. Hasil ini memberikan informasi bahwa perusahaan manufaktur selama periode penelitian lebih banyak yang menerima laporan audit tepat waktu.

\subsection{Menilai Keseluruhan Model Fit (Overall Fit Model)}

Untuk menilai Overall Fit Model terhadap data digunakan nilai likelihood L. Hipotesis yang diuji adalah sebagai berikut:

$\mathrm{H}_{0}$ : Model yang dihipotesiskan fit dengan data

$\mathrm{H}_{\mathrm{A}}$ : Model yang dihipotesiskan tidak fit dengan data

Uji keseluruhan model fit dilakukan dengan membandingkan nilai antara -2 LogLikelihood (-2LL) pada awal (Block Number $=0$ ) dengan nilai -2 Log Likelihood (2LL) pada akhir (Block Number $=1$ ). Jika terjadi penurunan nilai -2LL dari model awal (konstanta saja) ke model setelah variabel bebas dimasukkan, maka $\mathrm{H}_{0}$ diterima dan $\mathrm{H}_{\mathrm{A}}$ ditolak atau model yang dihipotesiskan fit dengan data.

Berdasarkan hasil uji menunjukkan adanya penurunan nilai -2LL sebesar 26,231. Nilai -2LL awal yakni sebesar 291,890 menjadi 265,659 setelah dimasukkan ketiga variabel independen. Berdasarkan hasil tersebut, maka $\mathrm{H}_{0}$ diterima dan $\mathrm{H}_{\mathrm{A}}$ ditolak, penurunan -2 Likelihood L (-2LL) ini menunjukkan model yang dihipotesiskan fit dengan data atau model regresi yang lebih baik.

\subsection{Menguji Koefisien Determinasi (Nagelkerke $R$ Square)}

Pengujian koefisien determinasi dilakukan untuk mengetahui seberapa besar kombinasi antara variabel independen mampu menjelaskan variasi dari variabel dependen. Nagelkerke $R$ Square merupakan modifikasi dari Cox and Snell $R$ Square yang dapat diintepretasikan seperti nilai $R$ Square pada regresi linier berganda (Ghozali, 2006).

\section{Tabel 1: Model Summary}




\begin{tabular}{|l|r|r|c|}
\hline Step & $\begin{array}{c}-2 \text { Log } \\
\text { likelihood }\end{array}$ & $\begin{array}{c}\text { Cox \& Snell } \\
\text { R Square }\end{array}$ & $\begin{array}{c}\text { Nagelkerke } \\
\text { R Square }\end{array}$ \\
\hline 1 & $265,659^{\text {a }}$ &, 076 &, 130 \\
\hline
\end{tabular}

Sumber : Hasil Pengolahan SPSS Versi 20, 2020

Berdasarkan tabel 1 di atas, nilai koefisien determinasi ditunjukkan dalam kolom Nagelkerke $R$ Square yakni sebesar 0,130. Hal ini menunjukkan bahwa variabel pergantian manajemen, audit fee, dan audit delay bersama-sama memberikan pengaruh mencapai $13 \%$ terhadap auditor switching, sedangkan sisanya $87 \%$ dipengaruhi oleh variabel lain yang tidak diteliti.

\subsection{Menguji Kelayakan Model Regresi}

Dalam menguji kelayakan model regresi menggunakan nilai statistik Hosmer and Lemeshow Goodness of Fit Test yang diukur dengan Chi-square. Nilai Chi-square harus lebih besar dari 0,05 yang menunjukkan bahwa model regresi yang digunakan diterima atau cocok dengan data penelitian.

Tabel 2: Hosmer and Lemeshow Test

\begin{tabular}{|l|r|r|c|}
\hline Step & Chi-square & df & Sig. \\
\hline 1 &, 000 & 1 & 1,000 \\
\hline
\end{tabular}

Sumber : Hasil Pengolahan SPSS Versi 20, 2020

Dari tabel 2 di atas dapat dilihat bahwa nilai Chi-square adalah sebesar 0 dengan nilai signifikansi sebesar 1. Dapat dikatakan bahwa nilai signifikan alpha $(\alpha)$ lebih besar dari 0,05 . Hal ini berarti model mampu memprediksi nilai observasinya atau terdapat kesesuaian model regresi yang digunakan dengan data penelitian. Sehingga analisis model regresi logistik layak untuk dilakukan lebih lanjut karena hipotesis nol tidak dapat ditolak (diterima).

\subsection{Uji Matriks Klasifikasi}

Uji matriks klasifikasi dilakukan untuk mengetahui kekuatan model regresi dalam memprediksi kemungkinan terjadinya auditor switching.

Tabel 3: Classification Table ${ }^{\mathrm{a}}$

\begin{tabular}{|c|c|c|c|c|c|c|}
\hline \multirow{3}{*}{\multicolumn{3}{|c|}{ Observed }} & \multicolumn{3}{|c|}{ Predicted } & \multirow{3}{*}{$\begin{array}{c}\text { Overall } \\
\text { Percentage }\end{array}$} \\
\hline & & & \multicolumn{2}{|c|}{ Switching Auditor } & \multirow{2}{*}{$\begin{array}{c}\text { Percentage } \\
\text { Correct }\end{array}$} & \\
\hline & & & \begin{tabular}{l|}
, 00 \\
\end{tabular} & 1,00 & & \\
\hline \multirow{2}{*}{ Step 1} & Non Switching &, 00 & 280 & 0 & 100,0 & \multirow[t]{2}{*}{85,6} \\
\hline & Auditor Switching & 1,00 & 48 & 5 & 9,4 & \\
\hline
\end{tabular}

Sumber : Hasil Pengolahan SPSS Versi 20, 2020

Dari tabel 3 di atas dapat diketahui bahwa kemampuan model regresi dalam memprediksi kemungkinan bagi perusahaan untuk melakukan auditor switching adalah sebesar 9,4\%. Dengan menggunakan model regresi yang digunakan, diprediksi terdapat 5 perusahaan $(9,4 \%)$ yang akan melakukan perpindahan KAP dari total 53 perusahaan yang melakukan perpindahan KAP. Sementara kekuatan prediksi model regresi untuk perusahaan yang tidak melakukan perpindahan KAP adalah sebesar 100\%, yang berarti bahwa dengan model regresi yang digunakan ada sebanyak 280 perusahaan (100\%) yang diprediksi tidak melakukan perpindahan KAP dari total 280 perusahaan yang tidak 
melakukan pergantian KAP. Jadi, kesimpulannya kekuatan prediksi dari model regresi adalah sebesar $85,6 \%$.

\subsection{Uji Model Regresi Logistik yang Terbentuk}

Pengujian regresi logistik (logistic regression) digunakan untuk menguji pengaruh pergantian manajemen, audit fee, dan audit delay terhadap auditor switching. Dalam menguji signifikansi koefisien dari setiap variabel independen, menggunakan nilai $p$ value (probability value)dengan tingkat signifikansi sebesar $5 \%(0,05)$.

1. Jika nilai probabilitas (sig.) $<\alpha=5 \%$ maka hipotesis didukung.

2. Jika nilai probabilitas (sig.) $>\alpha=5 \%$ maka hipotesis tidak didukung.

Tabel 4: Variables in the Equation

\begin{tabular}{|c|c|c|c|c|c|c|c|}
\hline & & B & S.E. & Wald & df & Sig. & $\operatorname{Exp}(B)$ \\
\hline \multirow{4}{*}{ Step $1^{\mathrm{a}}$} & CEO &,- 406 &, 402 & 1,022 & 1 & 312 & ,666 \\
\hline & AFEE & 22,920 & 17590,176 & ,000 & 1 & 999 & 8998227507,445 \\
\hline & AUDLY & 1,296 & ,473 & 7,521 & 1 & ,006 & 3,655 \\
\hline & Constant & $-1,807$ & 185 & 95,438 & 1 & 000 &, 164 \\
\hline
\end{tabular}

Sumber : Hasil Pengolahan SPSS Versi 20, 2020

Berdasarkan informasi dari tabel 4 di atas, hasil pengujian regresi logistik dapat dibuat persaman sebagai berikut:

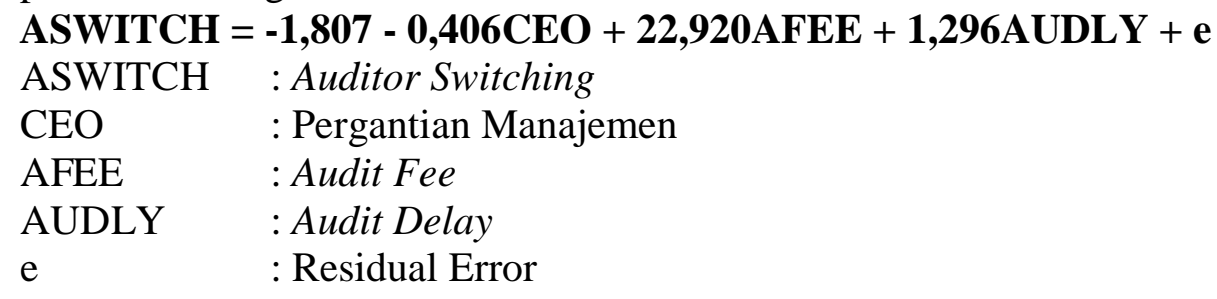

\section{PEMBAHASAN}

Tabel 5: Hasil Analisis Hipotesis

\begin{tabular}{|c|c|c|c|}
\hline Variabel & Sig & Keterangan & Hasil \\
\hline Pergantian Manajemen &, 312 & $\mathrm{H}_{1}$ Ditolak & Tidak Signifikan \\
\hline Audit Fee &, 999 & $\mathrm{H}_{2}$ Ditolak & Tidak Signifikan \\
\hline Audit Delay &, 006 & $\mathrm{H}_{3}$ Diterima & Signifikan \\
\hline
\end{tabular}

Sumber: Output SPSS 20, 2020

\section{Pengaruh Pergantian Manajemen terhadap Auditor Switching}

Hasil pengujian regresi logistik diperoleh bahwa variabel independen pergantian manajemen menunjukkan koefisien regresi negatif sebesar -0,406 dengan nilai signifikansi $(p)$ 0,312, lebih besar dari $\alpha=5 \%(0,05)$. Jadi dapat disimpulkan hipotesis pertama tidak didukung atau pergantian manajemen tidak berpengaruh terhadap auditor switching pada perusahaan manufaktur yang terdaftar di Bursa Efek Indonesia (BEI) selama periode2015-2017.

Pergantian manajemen dalam perusahaan seringkali diikuti dengan munculnya kebijakan baru. Seorang manajer yang baru akan berupaya untuk menjalankan perusahaan dengan gaya kepemimpinan yang berbeda dari pemimpin yang sebelumnya ke arah yang lebih baik. Dengan adanya perubahan kebijakan, selain akan membuat 
perusahaan lebih maju juga akan meningkatkan citra perusahaan di mata para investor. Perubahan kebijakan ini tidak berpengaruh terhadap keputusan manajemen dalam menunjuk auditor laporan keuangan. Manajemen yang baru merasa dengan melakukkan pergantian KAP justru akan membuat investor dan kreditur curiga jikalau manajemen yang baru mencari KAP yang bisa diajak bekerja sama. Perikatan dengan KAP baru diyakini lebih tidak independen dan opini yang dihasilkan bersifat bias. Hasil penelitian ini selaras dengan hasil penelitian (Damayanti \& Sudarma, 2008), (Juliantari \& Rasmini, 2013), serta (Nugroho \& Ghozali, 2015)\. Penelitian ini menunjukkan hasil bahwa pergantian manajemen tidak mempengaruhi auditor switching, artinya perusahaan yang melakukan auditor switching tidak selalu diikuti oleh pergantian manajemen.

\section{Pengaruh Audit Fee terhadap Auditor Switching}

Hasil pengujian regresi logistik didapatkan nilai koefisien regresi positif sebesar 22,920 dengan tingkat signifikansi $(p)$ sebesar 0,999, lebih besar dari $\alpha=5 \%(0,05)$. Jadi hipotesis kedua tidak didukung, artinya besarnya audit fee tidak berpengaruh terhadap auditor switching pada perusahaan manufaktur yang terdaftar di Bursa EfekIndonesia (BEI) selama periode 2015-2017.

Penawaran audit fee yang tinggi bukan merupakan suatu masalah jika diimbangi dengan kompetensi dan dapat sejalan dengan kualifikasi yang dibutuhkan oleh perusahaan (Ismaya, 2017). Manajemen berfungsi sebagai decision making yang memiliki sifat rasional, yaitu membandingkan antara cost dan benefit. KAP dengan penawaran fee yang tinggi namun tidak sejalan dengan harapan perusahaan diartikan sebagai memberikan cost yang tinggi dibandingkan benefit yang diterima (Dwiyanti \& Sabeni, 2014). Perusahaan dengan kondisi kesulitan keuangan tidak akan berpotensi melakukan pergantian auditor selama KAP dapat memberikan benefit yang lebih banyak dibandingkan dengan cost-nya. Hasil penelitian ini mendukung penelitian yang telah dilakukan sebelumnya oleh (Dwiyanti \& Sabeni, 2014) dan (Karliana, Susan, \& Yudowati, 2017) yang menunjukkan hasilbahwa audit fee tidak mempengaruhi dalam keputusan auditor switching.

\section{Pengaruh Audit Delay terhadap Auditor Switching}

Berdasarkan hasil pengujian regresi logistik, diperoleh nilai koefisien regresi positif sebesar 1,296 dengantingkat signifikansi $(p)$ sebesar 0,006, lebih kecil dari $\alpha=5 \%$ $(0,05)$. Jadi hipotesis ketiga diterima, artinya lamanya audit delay berpengaruh terhadap auditor switching pada perusahaan manufaktur yang terdaftar di Bursa Efek Indonesia (BEI) selama periode 2015-2017.

Lamanya waktu penyelesaian audit diukur dari tanggal tutup buku laporan keuangan yang diaudit hingga tanggal laporan auditor independen diterbitkan. Semakin lama waktu yang dibutuhkan auditor untuk menyelesaikan laporan akan semakin lama pula investor memperoleh informasi akuntansi yang termuat di laporan keuangan. Hal ini mengindikasikan bahwa investor akan lebih membutuhkan waktu dalam mempertimbangkan keputusan menanamkan modalnya di perusahaan yang bersangkutan. Kondisi ini menyebabkan perusahaan menjadi terlambat dalam memperoleh tambahan dana dalam membiayai kegiatan operasional, sehingga perusahaan memutuskan untuk melakukan auditor switching. Perusahaan meyakini bahwa dengan tidak mempertahkankan perikatan dengan KAP tidak akan menimbulkan kecurigaan terhadap investor. Hasil penelitian ini sejalan dengan penelitian sebelumnya yang dilakukan oleh (Pawitri \& Yadnyana, 2015), (Soraya \& Haridhi, 2017), dan (Sari, Deviyanti, \& Kusumawardani, 2018) yang menyatakan bahwa audit delay berpengaruh 
signifikan terhadap auditor switching. Jika terjadi audit delay perusahaan mungkin saja kehilangan investor yang hendak menanamkan modalnya karena laporan keuangan terlambat dipublikasikan. Sehingga hal tersebut akan memotivasi perusahaan untuk melakukan auditor switching.

\section{KESIMPULAN}

Berdasarkan hasil pengujian hipotesis diperoleh kesimpulan sebagai berikut:

1. Pergantian Manajemen (CEO). Berdasarkan hasil uji menunjukkan bahwa pergantian manajemen tidak mengakibatkan perusahaan akan merotasi auditor selama 3 tahun pengamatan (2015-2017). Dengan kata lain pergantian manajemen tidak berpengaruh terhadap auditor swtching.

2. Audit Fee (AFEE). Berdasarkan hasil uji menunjukkan bahwa audit fee tidak mengakibatkan perusahaan merotasi auditornya selama 3 tahun pengamatan (20152017). Jadi besarnya audit fee tidak berpengaruhterhadap auditor switching.

3. Audit Delay (AUDLY). Berdasarkan hasil uji menunjukkan bahwa audit delay berpengaruh terhadap keputusan auditor switching selama 3 tahun pengamatan (2015-2017) sehingga lamanya audit delay berpengaruh terhadap auditor switching.

\section{DAFTAR PUSTAKA}

(t.thn.). Diambil kembali dari http://www.ojk.go.id.

(t.thn.). Diambil kembali dari http://detikfinance.com.

Arisudhana, D. (2017). Pengaruh Audit Delay, Ukuran Klien, Opini Audit Tahun Sebelumnya, Reputasi Kantor Akuntan Publik, dan Return On Asset (ROA) terhadap Pergantian Auditor Sukarela . Jurnal Akuntansi dan Keuangan FEB Universitas Budi Luhur, Vol. 6, No.1, ISSN: 2252-7141.

Astuti, \& Ramantha. (2014). Pengaruh Audit Fee, Opini Going Concern, Financial Distress dan Ukuran Perusahaan pada Pergantian Auditor. E-Journal Akuntansi Universitas Udayana, Vol. 7, No.3. ISSN:2302-8556.

Chadegani, A. A., Mohamed, Z. M., \& Jari, A. (2011). The Determinant Factors of Auditor Switch Among Companies Listed on Tehran Stoock Exchange. International Conference on Sociality and Economics , Vol. 80. ISSN: 14502887.

Damayanti, S., \& Sudarma, M. (2008). Faktor-faktor yang Mempengaruhi Perusahaan Berpindah Kantor Akuntan Publik. Simposium Nasional Akuntansi XI , (hal. 113). Pontianak.

Dwiyanti, \& Sabeni. (2014). Faktor-Faktor Yang Mempengaruhi Auditor Switching Secara Voluntary . Diponegoro Journal of Accounting , Vol. 3, No. 3; 1-8.

Ghozali, I. (2006). Aplikasi Analisis Multivariate dengan Program SPSS. Semarang : Badan Penerbit Universitas Diponegoro.

Ismaya, N. (2017). Pengaruh Opini Audit, Pergantian Manajemen, Ukuran KAP, Ukuran Perusahaan Klien dan Audit Fee Terhadap Auditor Switching pada Perusahaan 
Jasa yang Terdaftar di BEI Tahun 2010-2015. Surakarta: Jurusan Akuntansi Fakultas Ekonomi dan Bisnis Institut Agama Islam Negeri Surakarta.

Juliantari, \& Rasmini. (2013). Auditor switching dan Faktor-faktor yang Mempengaruhinya. E-Journal Akuntansi Universitas Udayana, Vol. 3, No. 3.

Karliana, D., Susan, L., \& Yudowati, S. (2017). Pengaruh Opini Audit, Reputasi Auditor dan Audit Fee Terhadap Auditor Switching (Studi pada Perusahaan Sektor Infrasrtuktur, Utilitas, dan Transportasi yang Terdaftar di Bursa Efek Indonesia Tahun 2010-2015). E-Proceeding of Management (hal. Vol. 4,No. 2; 1740). Universitas Telkom.

Nasir, A. (2018). Pergantian Manajemen dan Fee Audit Terhadap Auditor Switching dengan Financial Distress sebagai Variabel Moderasi (Studi Empiris pada Perusahaan Real Estate \& Property yang Terdaftar di Bursa Efek Indonesia Tahun 2011-2016). JOM FEB , Vol. 1, Ed. 1.

Nugroho, D., \& Ghozali, I. (2015). Faktor-faktor yang Mempengaruhi Pergantian Auditor oleh Klien. Journal of Accounting Universitas Diponegoro , Vol. 4, No.4; 1-12.

Pawitri, N., \& Yadnyana, K. (2015). Pengaruh Audit Delay, Opini Audit, Reputasi Auditor, dan Pergantian Manajemen pada Voluntary Auditor Switching. Ejurnal Akuntansi Universitas Udayana, Vol.10, No.1; 214-228.

Praptika, P., \& Rasmini, N. (2016). Pengaruh Audit Tenure, Pergantian Auditor dan Financial Distress paa Audit Delay pada Perusahaan Consumer Goods. E-Jurnal Akuntansi Universitas Udayana, Vol. 15, No. 3. ISSN: 2302-8556.

Robbitasari, A., \& Wiratmaja, I. (2013). Pengaruh Opini Audit Going Concern, Kepemilikan Institutional dan Audit Delay pada Voluntary Auditor Switching. E-Jurnal Akuntansi Universitas Udayana, Vol. 5 No. 3; 652-665.

Sari, A. K., Deviyanti, D., \& Kusumawardani, A. (2018). Faktor-faktor yang Mempengaruhi Voluntary Auditor Switching pada Perusahaan yang Terdaftar di BEI Periode 2010-2015. Journal Fakultas Ekonomi dan Bisnis Universitas Mulawarman Samarinda, Vol. 15, No. 1; 17-28. ISSN: 2528-1135.

Sinarwati. (2010). Faktor-faktor yang Mempengaruhi Pergantian Kantor Akuntan Publik. Journal of Akuntabilitas , Vol. 19, No.2; 264-282.

Soraya, E., \& Haridhi, M. (2017). Faktor-faktor yang Mempengaruhi Voluntary Auditor Switching (Studi Empiris pada Perusahaan Non Financing yang Terdaftar di Bursa Efek Indonesia Tahun 2011-2015. Jurnal Ilmiah Mahasiswa Ekonomi Akuntansi Unsyiah, Vol. 2, No. 1; 48-62.

Wijayani, D. (2011). Analisis Faktor-Faktor yang Mempengaruhi Perusahaan di Indonesia Melakukan Auditor Switching. Semarang: Jurusan Akuntansi Fakultas Ekonomi Universitas Diponegoro. 